\title{
Influence of sulfur coated urea and algae fertilization on productivity of some leguminous crops in sandy soils
}

\author{
Reda Essa ${ }^{* *}$, Ahmed Afifi ${ }^{2}$ and Soad Ashry ${ }^{2}$
}

\begin{abstract}
Background: This studies the influence of algae and coated urea fertilization on the productivity of some leguminous crops in order to reach the best methods of fertilization to get on highest productivity in sandy soils.

Results: The results proved that both yield and its components a better result in the focus of the SCU + algae than utilizing sulfur-coated fertilizers and algae in both seasons. A large amount extreme yield and straw yield were established with the algae treatment. The outcomes uncovered that SCU + algae improved plant productivity and quality soybean and mungbean seeds. The utilization of SCU + algae expanded protein, carbohydrates and oil \%, compared with sulfur-coated urea and algae.
\end{abstract}

Conclusion: Along these lines, it could be finished from the results that of SCU + algae with $60 \mathrm{~kg} \mathrm{~N} / f e d$ observed to be the best portion to accomplish or gain with exertion the greatest quality.

Keywords: Sulfur-coated fertilizers (SCU), Algae, Soybean, Mungbean

\section{Background}

Soybean [Glycine max (L.) Merrill] is a standout among the mainly significant protein and oilseed crops all through the world. Its oil is the largest piece of the worlds ready to be eaten oils. Soybean is otherwise called the Golden bean or Miracle crop on account of its different employments. The mungbean legume crop is successfully absorbable, worthy to eat, nutritive, and no bombast. It is wealthy in absorbable protein (25-28\%), oil (1.0-1.5\%), fiber (3.5-4.5\%), ash (4.5-5.5\%) and carbohydrates (62$65 \%$ ), vitamin $\mathrm{C}$, folic acid, thiamine, iron, zinc, potassium, magnesium, copper, manganese, phosphorus an enemy of nourishing changeable that is the primary storage form of regular phosphorus in seeds (Sahar 2017). It assumes a significant job in the dirt prosperity by fixing the air, nitrogen (Dhole and Reddy 2015). The outcomes

\footnotetext{
*Correspondence: mashrera@yahoo.com

${ }^{1}$ Field Crop Res. Department, National Research Centre, Dokki, Giza,

Egypt

Full list of author information is available at the end of the article
}

demonstrated that algae application to improve the physiological exhibition of plants (Dela et al. 1988).

Microorganisms assume a significant role in soil forms that decide the plant productivity. There are a lot of soil microorganisms like Blue green algae, which can be utilized to increase the productivity of the plants (Goel et al. 1999; Fernandes and Bhalerao 2015). Natural manure means to improve biodiversity, biological cycles and soil biological faction to accomplish perfect characteristic frameworks that are socially, environmentally and economically sustainable (Samman et al. 2008). Nikhil (2014) showed that algae are limitless and various gatherings of basic, autotrophic living beings, running from unicellular to multicellular structure. Most of them can direct photosynthesis, and energy is changed into sugar, subsequently become biomass. Ruby and Mala (2014) found that the control, fertilizers have quickened the protein action amid germination and it was in charge of the observed addition in seed vigor index of mungbean. Bio-fertilizers are minimal attempt, inexhaustible sources of plant nutrients which supplement chemical fertilizers. Bio-fertilizer 
is a standout among the greatest and current apparatuses for agriculture, and they are also financially effective and inexhaustible source of energy for plants and to help in decreasing the utilization of chemical fertilizers for practicable farming (Wahane et al. 2020). It contains every one of the nutrients and plant development hormones, which is necessary for plants to improve yield (Latique et al. 2013).

The capacity of clear kinds of blue-green algae completes both photosynthesis and nitrogen fixation, which provide them biological and agricultural inclinations a different sort of bio-fertilizer, which can improve soil structure, mostly saline alkaline soil and increase the yielding and quality of crops. They are valuable in water refinement to some degree (Gupta et al. 2015). Algae improve soil structure and increment yield productivity regardless of whether connected in a little zone. The employment of algae in plants has brought about increment in root, shoot length with a number of leaves and thus by and a large improvement of the plant has been expanded (Vyomendra and Kumar 2016). Essa et al. (2019) showed that all forms of coated urea extended seed yields and straw yield by $3-16 \%$ and $2-18 \%$ independently for mungbean. The goal of this is to research the impact of algae and sulfur-coated urea (SCU) on yield and quality of soybean and mungbean under sandy soil conditions.

\section{Methods}

Two field experiments were approved out in two successive summer seasons, 2017 and 2018 at a private farm in Wadi El-Natroun, El-Behaira Governorate, Egypt. The goal of the study is to study the efficiency of sulphur coated urea (SCU) and algae fertilization on the yield and quality of soybean and mungbean under sandy soil conditions.

A representative surface soil sample $(0-30 \mathrm{~cm})$ was taken from experimental field before growing and after harvesting for each season to determine physical and chemical properties of the soil (Table 1), as well as the chemical analysis of the irrigated water.

The field experiments in both seasons were conducted under drip irrigation system with $30 \mathrm{~cm}$ distance between drippers $(2 \mathrm{~L} / \mathrm{hour})$ and $60 \mathrm{~cm}$ between rows. The plot size was $15 \mathrm{~m}^{2}$ (1/280 fed). Each plot consisted of five ridges $5 \mathrm{~m}$ long and $0.6 \mathrm{~m}$ wide. The irrigation system was settled at 3-4 day intervals. The experimental design was split-plot design in a randomized complete block arrangement with three replications. Fertilizers were allocated to the main plots, while rates of treatments were distributed at random in the subplots.

Well water was used for irrigating the experiments in order to maintain the soil moisture at about $60-70 \%$ of the soil water holding capacity (Table 2 ). To bring leaching, the experiment was occasionally irrigated with excess water. Metrological data for the growing period are given in (Table 3 ).

Soybean and mungbean were sown in May 15 in the 1st and 2nd seasons. Soybean (Giza 35) and mungbean (Kawmy-1) seeds were inoculated previous to sowing with the specific strain of Rhizobium japonicum. Soybean and mungbean in the rate of $30 \mathrm{~kg} / \mathrm{fed}\left(\mathrm{fed}=4200 \mathrm{~m}^{2}\right)$ were sown one side of the ridge in the hills $15 \mathrm{~cm}$ apart,

Table 1 Physico-chemical properties of the preferred experimental site during the two seasons

\begin{tabular}{|c|c|c|c|c|c|c|c|c|c|c|c|}
\hline \multirow[t]{2}{*}{ Growing season } & \multicolumn{5}{|c|}{ Particle size distribution (\%) } & \multirow{2}{*}{\multicolumn{2}{|c|}{ OM (\%) }} & \multirow[t]{2}{*}{$\mathrm{CaCO}_{3}^{-}(\%)$} & \multirow{2}{*}{\multicolumn{2}{|c|}{$\mathrm{pH}$}} & \multirow[t]{2}{*}{$E C\left(d S m^{-1}\right)$} \\
\hline & Sand & S & & Clay & Texture & & & & & & \\
\hline 2017 & 85.15 & & & 5.78 & Sandy & 0.23 & & 1.39 & & & 1.35 \\
\hline 2018 & 83.76 & & & 6.22 & Sandy & 0.35 & & 1.33 & & & 1.20 \\
\hline \multirow[t]{2}{*}{ Growing season } & \multicolumn{4}{|c|}{ Cations (1:2) (meq/L) } & \multicolumn{4}{|c|}{ Anions (1:2) (meq/L) } & \multicolumn{3}{|c|}{ NPK available (mg/kg) } \\
\hline & $\mathrm{Ca}^{++}$ & $\mathrm{Mg}^{++}$ & $\mathrm{Na}^{+}$ & $\mathrm{K}^{+}$ & $\mathrm{CO}_{3}=$ & $\mathrm{HCO}_{3}^{-}$ & $\mathrm{Cl}^{-}$ & $\mathrm{SO}_{4}=$ & $\mathrm{N}$ & $P$ & K \\
\hline 2017 & 2.20 & 1.70 & 5.50 & 1.60 & 0.00 & 2.35 & 7.35 & 1.30 & 33.22 & 72.34 & 115.42 \\
\hline 2018 & 2.15 & 1.72 & 5.25 & 1.63 & 0.00 & 2.20 & 7.30 & 1.25 & 23.28 & 79.34 & 98.22 \\
\hline
\end{tabular}

Table 2 Chemical analysis of irrigation water. (Average of two years)

\begin{tabular}{|c|c|c|c|c|c|c|c|c|c|}
\hline \multirow[t]{2}{*}{$\mathrm{pH}$} & \multirow[t]{2}{*}{$\mathrm{EC} \mathrm{dSm^{-1 }}$} & \multicolumn{4}{|c|}{ Soluble cations (mg/L) } & \multicolumn{4}{|c|}{ Soluble anions (mg/L) } \\
\hline & & $\mathrm{K}^{+}$ & $\mathrm{Na}^{+}$ & $\mathrm{Mg}^{++}$ & $\mathrm{Ca}^{++}$ & $\mathrm{CO}_{3}=$ & $\mathrm{HCO}_{3}^{-}$ & $\mathrm{Cl}^{-}$ & $\mathrm{SO}_{4}=$ \\
\hline 7.60 & 0.86 & 3.14 & 3.06 & 6.00 & 7.00 & 0.00 & 4.15 & 0.60 & 14.45 \\
\hline
\end{tabular}


Table 3 Metrological data of the growing period (2017/2018)

\begin{tabular}{|c|c|c|c|c|c|c|c|c|c|c|c|c|c|}
\hline Year & Month & Jan & Feb & Mar & Apr & May & Jun & Jul & Aug & Sep & Oct & Nov & Dec \\
\hline \multirow[t]{2}{*}{2017} & $\operatorname{Min}\left({ }^{\circ} \mathrm{C}\right)$ & 9 & 9 & 11 & 13 & 17 & 20 & 23 & 23 & 21 & 18 & 14 & 11 \\
\hline & $\operatorname{Max}\left({ }^{\circ} \mathrm{C}\right)$ & 18 & 19 & 21 & 24 & 27 & 29 & 30 & 30 & 30 & 28 & 24 & 20 \\
\hline \multirow[t]{2}{*}{2018} & $\operatorname{Min}\left({ }^{\circ} \mathrm{C}\right)$ & 9 & 9 & 11 & 14 & 16 & 20 & 23 & 23 & 21 & 17 & 14 & 10 \\
\hline & $\operatorname{Max}\left({ }^{\circ} \mathrm{C}\right)$ & 18 & 19 & 20 & 24 & 27 & 29 & 30 & 30 & 30 & 28 & 24 & 20 \\
\hline \multirow[t]{2}{*}{2017} & Prec.(mm) & 55 & 30 & 15 & 4 & 1 & 0 & 0 & 0 & 1 & 9 & 30 & 55 \\
\hline & Days & 11 & 9 & 6 & 2 & 1 & 0 & 0 & 0 & 0 & 3 & 5 & 10 \\
\hline \multirow[t]{2}{*}{2018} & Prec.(mm) & 51 & 27 & 13 & 4 & 1 & 0 & 0 & 0 & 1 & 11 & 29 & 52 \\
\hline & Days & 11 & 7 & 6 & 2 & 1 & 0 & 0 & 0 & 0 & 3 & 7 & 10 \\
\hline
\end{tabular}

and two plants/hill were left at thinning (21 days after sowing).

Phosphorus and potassium were additional at rate of $60 \mathrm{~kg} \mathrm{P}_{2} \mathrm{O}_{5} /$ fed and $50 \mathrm{~kg} \mathrm{~K}_{2} \mathrm{O} /$ fed, respectively. Phosphorus was applied as a single super phosphate $\left(15.5 \% \mathrm{P}_{2} \mathrm{O}_{5}\right)$ pre-sowing. Potassium was applied as potassium sulfate $\left(48 \% \mathrm{~K}_{2} \mathrm{O}\right)$ at 45 days after sowing in one dose. The second half portion of uncoated urea, sulfur-coated urea and algae were applied at two rates 30 and $60 \mathrm{~kg} / \mathrm{fed}$ at 20 days after sowing in one dose as in Table 4.

\section{Preparation of sulfur-coated urea fertilizer}

Several attempts were made to produce sulfur-coated urea (SCU) through coating with materials imposing their function physically. Several laboratory trials were carried out to synthesize sulfur containing 20\% pure coating material in a fine form. This was based on the idea of the physical incorporation of some completely soluble compounds containing $\mathrm{N}$, such as urea, in a media of coating material.

Urea was heated for $20 \mathrm{~min}$. and then receiving a mixture of conditioner and coating material, the whole being stirred for 30-40 min. to be finally removed to a drum. By heating to $70-80{ }^{\circ} \mathrm{C}$ and stirring again, the mixture in another drum was mixed with wax for 20-30 min. The final product was air-dried for one day, and sieved.
According to the method given by Trenkel (2010) and Essa (2015), the sulfur-coated urea was prepared at the field crops department included with soils and water use department, National Research Centre, Egypt.

\section{Preparation of algae}

The used algae in the present study Spirulina platens is a photosynthetic and multi-cellular blue green microalgae which grows in wide range fresh, marine and brackish water. The fresh algae material (One $\mathrm{kg}$ ) was cutted into small pieces and weighted. The sample was extracted using blender. The blended material was filtered through a double layered of muslin cloth to remove debris and designated as 100\% (Marrez et al. 2014). Samples were air-dried during 24 days followed by thermostat dry at $60^{\circ} \mathrm{C}$ for $12 \mathrm{~h}$, and dried algae were hand-crushed grind. The source of algae fresh is Algae Biotechnology Unit, NRC, Egypt. The plants were applied SCU and algae after 20 days from sowing, and the untreated plants were applied with urea (Table 5).

\section{Treatments nitrogen fertilizer rates were applied}

1. Control (Urea) $(46 \% \mathrm{~N}) 30$ and $60 \mathrm{~kg} \mathrm{~N} / \mathrm{fed}$

2. Sulfur-coated urea (SCU) $(33 \% \mathrm{~N}) 30$ and $60 \mathrm{~kg} \mathrm{~N} /$ fed.

Table 4 Rates of application ( $\mathrm{kg} \mathrm{N} / \mathrm{fed}$ ) and total amount of fertilizers

\begin{tabular}{|c|c|c|c|c|c|c|}
\hline \multirow[t]{2}{*}{ Fertilizers } & \multirow[t]{2}{*}{ Formula } & \multirow[t]{2}{*}{ N (\%) } & \multicolumn{2}{|l|}{ Soybean } & \multicolumn{2}{|l|}{ Mungbean } \\
\hline & & & Rate (kg N/fed) & $\begin{array}{l}\text { Amount (kg fert./ } \\
\text { fed) }\end{array}$ & Rate (kg N/fed) & $\begin{array}{l}\text { Amount } \\
\text { (kg fert./ } \\
\text { fed) }\end{array}$ \\
\hline \multirow[t]{2}{*}{ U } & \multirow[t]{2}{*}{$\mathrm{O}=\mathrm{C}\left(\mathrm{NH}_{2}\right)_{2}$} & \multirow[t]{2}{*}{46.00} & 30 & 65 & 30 & 65 \\
\hline & & & 60 & 130 & 60 & 130 \\
\hline \multirow[t]{2}{*}{ SCU } & \multirow[t]{2}{*}{$\mathrm{O}=\mathrm{C}\left(\mathrm{NH}_{2}\right)_{2}+\mathrm{S}$} & \multirow[t]{2}{*}{34.00} & 30 & 88 & 30 & 88 \\
\hline & & & 60 & 176 & 60 & 176 \\
\hline \multirow[t]{2}{*}{ Algae } & \multirow[t]{2}{*}{-} & \multirow[t]{2}{*}{11.50} & 30 & 260 & 30 & 260 \\
\hline & & & 60 & 520 & 60 & 520 \\
\hline
\end{tabular}


Table 5 Chemical composition and mineral concentration of algae

\begin{tabular}{|c|c|c|c|c|c|}
\hline \multicolumn{2}{|c|}{$\begin{array}{l}\text { Chemical } \\
\text { composition (\%) }\end{array}$} & \multicolumn{2}{|c|}{ Macronutrients (\%) } & \multicolumn{2}{|l|}{ Micronutrients (ppm) } \\
\hline Moisture & 6.42 & Nitrogen & 11.50 & Iron & 19.30 \\
\hline Protein & 15.60 & Phosphorus & 1.15 & Zinc & 7.76 \\
\hline Ash & 10.75 & Potassium & 1.96 & Manganese & 2.45 \\
\hline Fiber & 4.51 & Sodium & 0.02 & Lycine (mg/g) & 18.86 \\
\hline Carbohydrates & 20.82 & Magnesium & 0.11 & Methionine $(\mathrm{mg} / \mathrm{g})$ & 5.64 \\
\hline
\end{tabular}

3. Algae $(11.5 \% \mathrm{~N}) 30$ and $60 \mathrm{~kg} \mathrm{~N} / \mathrm{fed}$.

4. Mixed (SCU + Algae) (50:50) kg N/fed.

\section{Data recorded}

At harvest (120 days after sowing), ten plants were taken randomly from the two central rows guarded (from all plots) to determine the following traits:

\section{Plant height $(\mathrm{cm}) 2$. Seed weight/plant (g).}

All plants of each plot were harvested, and then, seed and straw yields (ton/fed) were determined by multiplying seed and straw yields/plot*280 (Kung et al. 2015).

\section{Methods of analysis}

For each plot, the following traits were done:

1. Method of soil analysis, physical and mineralogical properties according to Black (1982).

2. Method of soil analysis, chemical properties according to Black (1982).

3. Total nitrogen was determined by Kjeldahl method using the method described by Cottenie et al. (1982)

4. Crude Protein was calculated as N $\% \times 6.25$ according to the Association of Official Agricultural Chemists-A.O.A.C. (2000).

5. Total Carbohydrates were determined according to Dubois et al. (1956)

6. Seed oil percentage: the soxhlet continuous extraction apparatus with

7. petroleum ether $(40-60 \mathrm{C})$ as an organic solvent was used to determine the oil seed percentage according to A.O.A.C. (2000).

8. Phosphorus was determined spectrophotometricaly using the method described by Cottenie et al. (1982).
9. Potassium was determined using flame photometer as described by Cottenie et al. (1982).

10. Total carbon, organic carbon and organic matter were done according to Nelson and Summer (1982).

11. Statistical analyses were performed using the analysis of variance. The least significant differences LSD at $5 \%$ were used to compare between means. (Snedecor and Cochran 1990).

\section{Results \\ Soybean Yield attributes}

The collected data in Table 6 show the result of fertilizers with SCU, algae and mixed on soybean yield and its components. Results cleared significant differences the three studied fertilizers concerning the yield and its component. However, SCU + algae $(60 \mathrm{~kg} \mathrm{~N} / \mathrm{fed})$ agreed the top result of all yields and its component than SCU and algae in the two seasons.

On the other side, the differences between the fertilizers reached to the amount of significance in all yield and its components. It is worthy to mention that the superiority of SCU + algae fertilizers in all yield and its components had happened. However, SCU + algae fertilizers significantly affected all the individuality of soybean yield and its component compared to the control. The interaction stuck between algae and SCU was significant in the two seasons.

Data in Table 6 revealed that all treatments significantly increased straw yield/fed in both seasons. The increases of straw yield due to $\mathrm{SCU}+$ algae treatment more than the SCU and algae in the two seasons, respectively.

Generally, SCU+algae fertilizers resulted in height values of yield and its components compared with SCU and algae. It could be completed from the obtained results that SCU + algae with $60 \mathrm{~kg} \mathrm{~N} /$ fed found to be the majority helpful dose to achieve the highest yield and its components.

\section{Seed quality attributes}

The results presented in Table 7 indicated that adopted treatments of algae and SCU showed a helpful statistical result on the seed nitrogen percentage of the soybean in together growing seasons. It is realized from Table 7 that SCU, algae and mixed treatments significantly better grain, crude protein percentage of soybean seeds in both seasons. The maximum percentage of seed crude protein was recorded with SCU+algae in both seasons more than the SCU and algae treatment in the first and second season, respectively. 
Table 6 Effect of algae and sulfur-coated urea fertilizers on yield and yield component of soybean

\begin{tabular}{|c|c|c|c|c|c|c|c|c|c|c|c|c|}
\hline \multirow[t]{2}{*}{ Sources } & \multicolumn{2}{|c|}{ Plant height (cm) } & \multirow[t]{2}{*}{ Mean } & \multicolumn{2}{|c|}{ Seed yield /plant (g) } & \multirow[t]{2}{*}{ Mean } & \multicolumn{2}{|c|}{$\begin{array}{l}\text { Seed yield (ton/ } \\
\text { fed) }\end{array}$} & \multirow[t]{2}{*}{ Mean } & \multicolumn{2}{|c|}{$\begin{array}{l}\text { Straw yield (ton/ } \\
\text { fed) }\end{array}$} & \multirow[t]{2}{*}{ Mean } \\
\hline & 30 & 60 & & 30 & 60 & & 30 & 60 & & 30 & 60 & \\
\hline \multicolumn{13}{|l|}{2017} \\
\hline Control & 88.67 & 89.33 & 89.00 & 12.33 & 12.33 & 12.33 & 0.79 & 0.81 & 0.80 & 1.33 & 1.35 & 1.34 \\
\hline SCU & 97.00 & 116.00 & 106.50 & 14.74 & 20.02 & 17.38 & 0.94 & 1.33 & 1.14 & 1.78 & 2.12 & 1.95 \\
\hline Algae & 104.00 & 118.00 & 111.00 & 17.21 & 20.23 & 18.72 & 1.03 & 1.35 & 1.19 & 1.94 & 2.33 & 2.14 \\
\hline $\mathrm{SCU}+$ Algae & 109.00 & 126.00 & 117.50 & 18.89 & 21.27 & 20.08 & 1.09 & 1.40 & 1.25 & 1.88 & 2.49 & 2.19 \\
\hline Mean & 99.67 & 112.33 & 106.00 & 15.79 & 18.46 & 17.13 & 0.96 & 1.22 & 1.09 & 1.73 & 2.07 & 1.90 \\
\hline \multirow[t]{3}{*}{$\operatorname{LSD}_{0.05}$} & Sources 2.90 & & & 1.15 & & & 0.05 & & & 0.07 & & \\
\hline & Rates 1.43 & & & 0.94 & & & 0.03 & & & 0.03 & & \\
\hline & $S \times R 2.85$ & & & 1.87 & & & 0.06 & & & 0.06 & & \\
\hline \multicolumn{13}{|l|}{2018} \\
\hline Control & 91.67 & 92.00 & 91.84 & 12.00 & 13.00 & 12.50 & 0.87 & 0.89 & 0.88 & 1.37 & 1.40 & 1.39 \\
\hline SCU & 103.00 & 131.00 & 117.00 & 14.87 & 19.81 & 17.34 & 1.03 & 1.42 & 1.23 & 1.89 & 2.22 & 2.06 \\
\hline Algae & 113.00 & 130.00 & 121.50 & 16.21 & 20.36 & 18.29 & 1.07 & 1.46 & 1.27 & 1.95 & 2.38 & 2.17 \\
\hline $\mathrm{SCU}+$ Algae & 117.00 & 141.00 & 129.00 & 19.10 & 22.01 & 20.56 & 1.24 & 1.49 & 1.37 & 2.02 & 2.51 & 2.27 \\
\hline Mean & 106.17 & 123.50 & 114.83 & 15.55 & 18.80 & 17.17 & 1.05 & 1.32 & 1.18 & 1.76 & 2.08 & 1.92 \\
\hline \multirow[t]{3}{*}{$\mathrm{LSD}_{0.05}$} & Sources 2.64 & & & 1.36 & & & 0.05 & & & 0.02 & & \\
\hline & Rates 0.84 & & & 0.56 & & & 0.04 & & & 0.03 & & \\
\hline & S x R 1.68 & & & 1.12 & & & 0.08 & & & 0.06 & & \\
\hline
\end{tabular}

$\mathrm{S} \times \mathrm{R}=$ Sources $\times$ Rates

Table 7 Effect of algae and sulfur-coated urea fertilizers on quality of soybean

\begin{tabular}{|c|c|c|c|c|c|c|c|c|c|c|c|c|}
\hline \multirow[t]{2}{*}{ Sources } & \multicolumn{2}{|l|}{$\begin{array}{l}\text { Nitrogen } \\
(\%)\end{array}$} & \multirow[t]{2}{*}{ Mean } & \multicolumn{2}{|l|}{$\begin{array}{l}\text { Protein } \\
(\%)\end{array}$} & \multirow[t]{2}{*}{ Mean } & \multicolumn{2}{|c|}{$\begin{array}{l}\text { Carbohydrates } \\
(\%)\end{array}$} & \multirow[t]{2}{*}{ Mean } & \multicolumn{2}{|l|}{$\begin{array}{l}\text { Oil } \\
(\%)\end{array}$} & \multirow[t]{2}{*}{ Mean } \\
\hline & 30 & 60 & & 30 & 60 & & 30 & 60 & & 30 & 60 & \\
\hline \multicolumn{13}{|l|}{2017} \\
\hline Control & 2.96 & 3.00 & 2.98 & 18.50 & 18.75 & 18.63 & 23.67 & 24.00 & 23.84 & 17.67 & 18.00 & 17.84 \\
\hline SCU & 3.90 & 4.21 & 4.06 & 24.38 & 26.31 & 25.35 & 30.70 & 33.30 & 32.00 & 20.19 & 22.82 & 21.51 \\
\hline Algae & 4.01 & 4.29 & 4.15 & 25.06 & 26.81 & 25.94 & 31.11 & 35.20 & 33.16 & 20.49 & 22.92 & 21.71 \\
\hline SCU + Algae & 4.09 & 4.42 & 4.26 & 25.56 & 27.63 & 26.60 & 31.75 & 35.12 & 33.44 & 20.75 & 23.13 & 21.94 \\
\hline Mean & 3.74 & 3.98 & 3.86 & 23.38 & 24.88 & 24.13 & 29.31 & 31.91 & 30.61 & 19.78 & 21.72 & 20.75 \\
\hline \multirow[t]{3}{*}{$\mathrm{LSD}_{0.05}$} & Sources 0.15 & & & 0.95 & & & 0.60 & & & 0.78 & & \\
\hline & Rates 0.13 & & & 0.84 & & & 0.39 & & & 0.19 & & \\
\hline & $\mathrm{S} \times \mathrm{RnS}$ & & & Ns & & & 0.78 & & & 0.39 & & \\
\hline \multicolumn{13}{|l|}{2018} \\
\hline Control & 3.13 & 3.15 & 3.14 & 19.58 & 19.69 & 19.64 & 24.00 & 24.67 & 24.34 & 18.00 & 19.00 & 18.50 \\
\hline SCU & 3.94 & 4.28 & 4.11 & 24.63 & 26.75 & 25.69 & 31.12 & 33.77 & 32.45 & 20.59 & 22.86 & 21.73 \\
\hline Algae & 4.05 & 4.38 & 4.22 & 25.31 & 27.38 & 26.35 & 31.24 & 36.00 & 33.62 & 20.58 & 23.01 & 21.80 \\
\hline SCU + Algae & 4.18 & 4.53 & 4.36 & 26.13 & 28.31 & 27.22 & 31.92 & 37.13 & 34.53 & 20.86 & 23.95 & 22.41 \\
\hline Mean & 3.83 & 4.09 & 3.96 & 23.91 & 25.53 & 24.72 & 29.57 & 32.89 & 31.23 & 20.01 & 22.21 & 21.11 \\
\hline \multirow[t]{3}{*}{$\mathrm{LSD}_{0.05}$} & Sources 0.04 & & & 0.26 & & & 0.87 & & & 0.23 & & \\
\hline & Rates 0.03 & & & 0.23 & & & 0.62 & & & 0.68 & & \\
\hline & $S \times R 0.07$ & & & 0.46 & & & 1.25 & & & Ns & & \\
\hline
\end{tabular}

$\mathrm{S} \times \mathrm{R}=$ Sources $\times$ Rates 
The results in Table 7 clearly show that treatments of $\mathrm{SCU}+$ algae significantly increased total carbohydrates in two seasons. The greatest increase in the total carbohydrates in both seasons recorded more than the SCU and algae in the first and second seasons, respectively.

The data also revealed that SCU + algae significantly surpassed SCU and algae in carbohydrate in both seasons. The oil content was positively affected by $\mathrm{SCU}$, algae and mixed treatments in both seasons (Table 7). Fertilizer treatments of SCU+algae significantly increased the mean of the seed oil of soybean in both seasons. The increases more than the SCU+algae due to SCU and algae treatments in the tow seasons, respectively.

Generally, algae fertilizers resulted in higher values of quality compared with SCU and algae. Therefore, it could be finished from the obtained results that of $\mathrm{SCU}+$ algae with $60 \mathrm{~kg} \mathrm{~N} /$ fed found to be the mainly useful dose to achieve the highest quality.

The interaction between algae and SCU was significant in both seasons except for nitrogen and protein in first season and oil in second season.

\section{Mungbean}

\section{Yield attributes}

Data in Table 8 revealed that all treatments significantly improved plant height in both seasons. The increases in the plant height due to SCU + algae treatment over the control. The data show that SCU+algae $(60 \mathrm{~kg} / \mathrm{fed})$ surpassed SCU and algae in a seed yield/plant in the first and second seasons.

Data of seed yield/fed of mungbean as affected by $\mathrm{SCU}+$ algae are given in Table 8 The obtained consequences revealed that all treatments with $\mathrm{SCU}$ and algae significantly increased mungbean yield of seeds/fed in both seasons. It is clear that $\mathrm{SCU}+$ algae fertilizers significantly surpassed SCU and algae in both seasons. The highest increases of seeds yield/fed were obtained by $\mathrm{SCU}+$ algae $(7.02$ and $4.76 \%$ ) over the control treatment in both seasons, respectively. It is worthy to note that the increase in seed yield could be mainly approved to the increase in the seeds/fed.

Data in Table 8 revealed that all treatments significantly increased straw yield/fed in both seasons. The increases of straw yield due to SCU+algae treatment were (5.91 and $4.98 \%$ ) over the control in the first and second seasons, respectively.

Generally, SCU + algae fertilizers resulted in great values of yield and its components compared with SCU and algae. Therefore, it could be concluded that algae with $60 \mathrm{~kg} \mathrm{~N} /$ fed found to be the most successful dose to achieve the maximum yield and its components.

The interaction between algae and SCU were significant in both seasons except seed yield/plant and seed yield in first season and except for plant height, seed yield/plant and straw yield/fed in second season.

Table 8 Effect of algae and sulfur-coated urea fertilizers on yield and yield component of mungbean

\begin{tabular}{|c|c|c|c|c|c|c|c|c|c|c|c|c|}
\hline \multirow[t]{2}{*}{ Sources } & \multicolumn{2}{|l|}{$\begin{array}{l}\text { Plant height } \\
(\mathrm{cm})\end{array}$} & \multirow[t]{2}{*}{ Mean } & \multicolumn{2}{|c|}{$\begin{array}{l}\text { Seed yield /plant } \\
\text { (g) }\end{array}$} & \multirow[t]{2}{*}{ Mean } & \multicolumn{2}{|c|}{$\begin{array}{l}\text { Seed yield (ton/ } \\
\text { fed) }\end{array}$} & \multirow[t]{2}{*}{ Mean } & \multicolumn{2}{|c|}{$\begin{array}{l}\text { Straw yield (ton/ } \\
\text { fed) }\end{array}$} & \multirow[t]{2}{*}{ Mean } \\
\hline & 30 & 60 & & 30 & 60 & & 30 & 60 & & 30 & 60 & \\
\hline \multicolumn{13}{|l|}{2017} \\
\hline Control & 121.00 & 123.00 & 122.00 & 6.30 & 6.98 & 6.64 & 0.77 & 0.83 & 0.80 & 1.89 & 1.93 & 1.91 \\
\hline SCU & 137.67 & 143.00 & 140.34 & 8.16 & 8.39 & 8.28 & 1.00 & 1.12 & 1.06 & 2.26 & 2.52 & 2.39 \\
\hline Algae & 139.33 & 146.33 & 142.83 & 8.20 & 8.52 & 8.36 & 1.04 & 1.15 & 1.10 & 2.42 & 2.62 & 2.52 \\
\hline $\mathrm{SCU}+$ Algae & 142.83 & 151.50 & 147.17 & 8.25 & 8.60 & 8.43 & 1.06 & 1.22 & 1.14 & 2.45 & 2.63 & 2.54 \\
\hline Mean & 135.21 & 140.96 & 138.08 & 7.73 & 8.12 & 7.93 & 0.97 & 1.08 & 1.02 & 2.26 & 2.43 & 2.34 \\
\hline \multirow[t]{3}{*}{$\mathrm{LSD}_{0.05}$} & Sources 2.74 & & & 0.53 & & & 0.07 & & & 0.11 & & \\
\hline & Rates 1.30 & & & 0.30 & & & 0.04 & & & 0.04 & & \\
\hline & $S \times R 2.60$ & & & ns & & & ns & & & 0.08 & & \\
\hline \multicolumn{13}{|l|}{2018} \\
\hline Control & 126.00 & 130.00 & 128.00 & 7.30 & 7.43 & 7.37 & 0.82 & 0.86 & 0.84 & 1.92 & 2.04 & 1.98 \\
\hline SCU & 140.00 & 146.00 & 143.00 & 9.56 & 10.29 & 9.93 & 1.13 & 1.26 & 1.20 & 2.30 & 2.66 & 2.48 \\
\hline Algae & 142.33 & 147.33 & 144.83 & 9.80 & 10.32 & 10.06 & 1.20 & 1.31 & 1.26 & 2.43 & 2.69 & 2.56 \\
\hline $\mathrm{SCU}+$ Algae & 145.33 & 154.67 & 150.00 & 10.09 & 10.60 & 10.35 & 1.26 & 1.37 & 1.32 & 2.52 & 2.70 & 2.61 \\
\hline Mean & 138.42 & 144.50 & 141.46 & 9.19 & 9.66 & 9.42 & 1.10 & 1.20 & 1.15 & 2.29 & 2.52 & 2.41 \\
\hline \multirow[t]{3}{*}{$\mathrm{LSD}_{0.05}$} & Sources 2.71 & & & 0.32 & & & 0.04 & & & 0.06 & & \\
\hline & Rates 1.97 & & & 0.20 & & & 0.02 & & & 0.05 & & \\
\hline & SxRns & & & ns & & & 0.03 & & & ns & & \\
\hline
\end{tabular}


Table 9 Effect of algae and sulfur-coated urea fertilizers on quality of mungbean

\begin{tabular}{|c|c|c|c|c|c|c|c|c|c|c|c|c|}
\hline \multirow[t]{2}{*}{ Sources } & \multicolumn{2}{|l|}{$\begin{array}{l}\text { Nitrogen } \\
(\%)\end{array}$} & \multirow[t]{2}{*}{ Mean } & \multicolumn{2}{|l|}{$\begin{array}{l}\text { Protein } \\
(\%)\end{array}$} & \multirow[t]{2}{*}{ Mean } & \multicolumn{2}{|c|}{$\begin{array}{l}\text { Carbohydrates } \\
(\%)\end{array}$} & \multirow[t]{2}{*}{ Mean } & \multicolumn{2}{|l|}{$\begin{array}{l}\text { Oil } \\
(\%)\end{array}$} & \multirow[t]{2}{*}{ Mean } \\
\hline & 30 & 60 & & 30 & 60 & & 30 & 60 & & 30 & 60 & \\
\hline \multicolumn{13}{|l|}{2017} \\
\hline Control & 2.25 & 2.28 & 2.27 & 14.06 & 14.25 & 14.16 & 29.37 & 41.67 & 35.52 & 1.12 & 1.16 & 1.14 \\
\hline SCU & 2.98 & 3.05 & 3.02 & 18.63 & 19.06 & 18.85 & 46.32 & 51.09 & 48.71 & 1.17 & 1.30 & 1.24 \\
\hline Algae & 3.16 & 3.30 & 3.23 & 19.75 & 20.63 & 20.19 & 49.00 & 53.51 & 51.26 & 1.25 & 1.40 & 1.33 \\
\hline $\mathrm{SCU}+$ Algae & 3.27 & 3.39 & 3.33 & 20.44 & 21.19 & 20.82 & 47.45 & 54.00 & 50.73 & 1.29 & 1.45 & 1.37 \\
\hline Mean & 2.92 & 3.01 & 2.96 & 18.22 & 18.78 & 18.50 & 43.04 & 50.07 & 46.55 & 1.21 & 1.33 & 1.27 \\
\hline \multirow[t]{3}{*}{$\operatorname{LSD}_{0.05}$} & Sources 0.11 & & & 0.59 & & & 1.79 & & & 0.07 & & \\
\hline & Rates 0.07 & & & 0.42 & & & 2.01 & & & 0.06 & & \\
\hline & $\mathrm{S} \times \mathrm{Rns}$ & & & ns & & & ns & & & ns & & \\
\hline \multicolumn{13}{|l|}{2018} \\
\hline Control & 2.40 & 2.52 & 2.46 & 15.00 & 15.75 & 15.38 & 42.50 & 46.67 & 44.59 & 1.15 & 1.23 & 1.19 \\
\hline SCU & 3.04 & 3.12 & 3.08 & 19.00 & 19.50 & 19.25 & 48.79 & 53.79 & 51.29 & 1.29 & 1.39 & 1.34 \\
\hline Algae & 3.27 & 3.39 & 3.33 & 20.44 & 21.19 & 20.82 & 51.00 & 55.51 & 53.26 & 1.34 & 1.48 & 1.41 \\
\hline $\mathrm{SCU}+$ Algae & 3.37 & 3.49 & 3.43 & 21.06 & 21.81 & 21.44 & 49.15 & 55.70 & 52.43 & 1.41 & 1.57 & 1.49 \\
\hline Mean & 3.02 & 3.13 & 3.08 & 18.88 & 19.56 & 19.22 & 47.86 & 52.92 & 50.39 & 1.30 & 1.42 & 1.36 \\
\hline \multirow{3}{*}{$\mathrm{LSD}_{0.05}$} & Sources 0.09 & & & 0.53 & & & 2.93 & & & 0.07 & & \\
\hline & Rates 0.04 & & & 0.28 & & & 1.67 & & & 0.05 & & \\
\hline & $S \times R n s$ & & & ns & & & ns & & & ns & & \\
\hline
\end{tabular}

$\mathrm{S} \times \mathrm{R}=$ Sources $\times$ Rates

\section{Seed quality attributes}

The results in Table 9 showed that adopted treatments of $\mathrm{SCU}+$ algae showed a constructive statistical result on the seed nitrogen $\%$ of the mungbean in both seasons. It is achieved from Table 9 that SCU + algae treatment significantly increased grain, crude protein \% of mungbean seeds in both seasons. The maximum percentage of seed crude protein was recorded by SCU + algae in both seasons in excess of the SCU and algae treatment in the first and second season, respectively.

Data in Table 9 clearly show that the treatment, $\mathrm{SCU}+$ algae significantly increased total carbohydrates in both seasons. The maximum increase in both seasons recorded by $\mathrm{SCU}+$ algae more the $\mathrm{SCU}$ and algae in the first and second seasons, respectively. Data also showed that SCU+algae significantly surpassed SCU and algae in carbohydrate in both seasons. The oil content was positively precious by SCU, algae and mixed treatments in both seasons (Table 9). Fertilizer treatments of $\mathrm{SCU}+$ algae significantly increased the average of the seed oil of mungbean in both seasons, respectively.

Generally, algae fertilizers resulted in superior values of quality compared with SCU+algae. Therefore, it could be concluded that SCU+algae with $60 \mathrm{~kg} \mathrm{~N} /$ fed found to be the mostly helpful quantity to achieve the most quality.
The interaction stuck between algae and SCU was no significant in the two seasons.

\section{Economic feasibility}

Individually of the crops has two types of yield harvest (seeds and straw). According to the price of all yield product, the economic feasibility was calculated as in Table 10 for the average of the two seasons.

According to the data, the highly total income was for the accumulation of SCU with algae (50:50) followed by the adding of the algae and SCU alone, while the control was the least income.

\section{Discussions}

In this connection, Ali and Mostafa (2009) reported that the similar results on peanut and maize. Using algae fertilizer in such soil showed a superior means in that affect where it is careful as an imperative group of microorganisms capable of fixing atmospheric nitrogen. Algae naturally contain ouxin, cytokines and gibberellic acid and activate some enzymes as dehydrogenises, pretenses, peptidases and phosphohydrolases (Crouch and Van Stander 1991).

In this relation, the results in this study cleared that there was a wide difference between the algae and SCU of soybean and mungbean plant in their response of yield 
Table 10 Economic feasibility of algae and sulfur-coated urea fertilizers on yield of soybean and mungbean. (Average of two years)

\begin{tabular}{|c|c|c|c|c|c|}
\hline \multirow[t]{2}{*}{ Fertilizers } & \multicolumn{5}{|l|}{ Soybean } \\
\hline & Seed yield (ton/fed) & $\begin{array}{l}\text { Price } \\
\text { (L.E.) }\end{array}$ & Straw yield (ton/fed) & $\begin{array}{l}\text { Price } \\
\text { (L.E.) }\end{array}$ & Total yield income \\
\hline Control (U) & 0.85 & 6800 & 1.38 & 3450 & 10,250 \\
\hline SCU & 1.38 & 11,040 & 2.17 & 5425 & 16,465 \\
\hline Algae & 1.41 & 11,280 & 2.36 & 5900 & 17,180 \\
\hline $\mathrm{SCU}+$ algae & 1.45 & 11,600 & 2.50 & 6250 & 17,850 \\
\hline $\begin{array}{l}\text { Seed yield of soybean }=8 \\
\text { L.E } / \mathrm{kg}\end{array}$ & & & & $\begin{array}{l}\text { Straw yield of soybean }=2.5 \\
\text { L.E } / \mathrm{kg}\end{array}$ & \\
\hline \multirow[t]{2}{*}{ Fertilizers } & \multicolumn{5}{|l|}{ Mungbean } \\
\hline & Seed yield (ton/fed) & $\begin{array}{l}\text { Price } \\
\text { (L.E.) }\end{array}$ & Straw yield (ton/fed) & $\begin{array}{l}\text { Price } \\
\text { (L.E.) }\end{array}$ & Total yield income \\
\hline Control (U) & 0.85 & 8500 & 1.99 & 3980 & 12,480 \\
\hline SCU & 1.19 & 11,900 & 2.59 & 5180 & 17,080 \\
\hline Algae & 1.23 & 12,300 & 2.66 & 5320 & 17,620 \\
\hline SCU + algae & 1.30 & 13,000 & 2.67 & 5340 & 18,340 \\
\hline $\begin{array}{l}\text { Seed yield of mungbean }=10 \\
\text { L.E/kg }\end{array}$ & & & & $\begin{array}{l}\text { Straw yield of mungbean }=2 \\
\text { L.E } / \mathrm{kg}\end{array}$ & \\
\hline
\end{tabular}

and yield components. Regarding the treatments, the outcome showed that $60 \mathrm{~kg} \mathrm{~N} /$ fed was promising and gave an encouraging result. This product may be attributed to algae fertilizers added helpful to the crop plants than the ordinary chemical fertilizers. Also, El-Umolari and Rengasamy (2012) showed that seaweed contains macro- and micronutrients and amino acids which encourage the growth and yield plants.

More than that, the physiological factors, including of inefficient partitioning of assimilating poor pod setting, too some flower abscission and lack of nutrients during the critical stages of soybean and mungbean growth. In the present study, it was shown that the additionally of algae increased the seed weight/plant and finally seed yield per plant which are the largely important yield determining components in soybean and mungbean. The increased yield attributes may be due to the presence of various growth promoting substances such as IAA and IBA, gibberellins, cytokinins, micronutrients and amino acids. This is in conformity with the result reported for Ganesh et al. 2015; Zodape et al. 2010; Venkata Rao et al. 2015 and Vyomendra and Kumar 2016.

Finally, application of the algae and SCU fertilizers to soybean and mungbean caused improve in plant height, seed weight/plant, seed yield/fed., straw yield, crude protein \%, total carbohydrates and oil \%. The effects may be because of the helpful cause algae on a plant which instruction of nutrient algae and increase the nitrogen use efficiency by plant compare to SCU fertilizers and reducing $\mathrm{N}$ leaching losses and provide a constant supply of nutrients to the root. This algae also provides an efficient way of applying nitrogen to such soils to enhance the efficiency of $\mathrm{N}$ use and the minimize leaching as well as to prevent environmental pollution by the excess nitrogen in the soil. In this connection, Latique et al. (2013) and Nikhil (2014) mentioned that application of algae significantly increased NPK, crude protein content, total carbohydrates and oil \% of soybean and mungbean seeds.

\section{Conclusion}

In this research, trial proof shows that algae fertilizers are successful and superior grain yield of soybean and mungbean. The grain yield of soybean and mungbean was extended by use of SCU + algae, in both seasons, respectively, at $60 \mathrm{~kg} \mathrm{~N} / \mathrm{fed}$ in treatments. This may be because of the statement get of development, advancing substances such as, gibberellins, cytokinins, nutrients, amino acids and micronutrients. It may be that algae fertilizer could serve as cost effective, eco-friendly product for sustainable agriculture, yet their dimension should be proper to upgrade development and profitability. However, long-term effects, such as those that might occur from potential soil sulfur accumulation more several years.

This paper concisely underlines the use of algae fertilizers as an important tool for sustainability and other choice use against the chemical fertilizers. Therefore, this fertilizer can be viewed as the new decision and unlimited advancing sustainable agriculture. Algae not only 
provide nutrients to the plants, but in fact also help in increasing plant growth and soil fertility.

\author{
Abbreviations \\ O.M: Organic matter; $\mathrm{P}^{\mathrm{H}}$ : Acidity; $\mathrm{CaCO}_{3}$ : Calcium Carbonates; E.C.: Electric \\ Conductivity; Carb.: Carbohydrates; SCU: Sulfur-coated urea; P: Phosphorus; \\ $\mathrm{K}$ : Potassium; Cl: Chlorine; $\mathrm{HCO}_{3}$ : Bicarbonate; LSD: Least significant degree; \\ L.E.: Egyptian pound; U: Urea; Kg: Kilo gram; N: Nitrogen; $\mathrm{CO}_{3}$ : Carbonate; $\mathrm{Ca}$ : \\ Calcium; $\mathrm{SO}_{4}$ : Sulfate.
}

\section{Acknowledgements}

The author(s) are thankful to the Director a private farm in Wadi El-Natroun, ElBehaira Governorate, Egypt, for providing all the necessary facility to complete the research work.

\section{Authors' contributions}

This work was carried out in collaboration between all authors. Author R.E. designed the study, the field works; the literature searches, tabled the field data for the statistical analyses, prepared the samples for analyses and reviewed the final draft of manuscript. Author A.A. participated in the field works; tabled the data for statistical analyses and reviewed the final draft of manuscript. Author S.E. conducted the field applications, prepared the samples for analyses, conducted the physical and chemical analyses, and reviewed the final draft of manuscript. All authors read and approved the final manuscript.

\section{Funding}

Not applicable.

\section{Availability of data and materials}

All data during this study are included in this published article.

\section{Declarations}

Ethics approval and consent to participate

Not applicable.

\section{Consent for publication}

Not applicable.

\section{Competing interests}

The authors declare that they have no competing interests.

\section{Author details}

${ }^{1}$ Field Crop Res. Department, National Research Centre, Dokki, Giza, Egypt.

${ }^{2}$ Soil and Water Department, National Research Centre Dokki, Giza, Egypt.

Received: 11 December 2020 Accepted: 8 March 2021

Published online: 17 March 2021

\section{References}

Ali KM, Mostafa SM (2009) Evaluation of potassium humate and Spirulina platens is as bio-organic fertilizer for sesame plants grown under salinity stress. Egypt J Agric Res 87:369-388

Association of Official Agricultural Chemists (A.O.A.C.), (2000) Official Methods of Analysis, 15th edn. AOAC, Washington, D.C., p 55

Black, C.A. (1982). Methods of Soil Analysis, Part 2, 2nd Ed., Ch.8, 18. Amer. Soc. Agronomy No. 9, Madison, Wisconsin, USA

Cottenie A, Verloo M, Velghe M, Camerlgnck R (1982) Chemical analysis of plant and soils laboratory of Analytical and Agro Chemistry State Univ. Ghent, Belgium

Crouch JJ, Stander V (1991) Evidence for rooting factors in a seaweed preparation from Eckionia maxima. J Plant Physiol 137:319-322

Dela CRE, Manalo MQ, Aganagan NS, Tambalo JD (1988) Growth of three legume trees included with VA mycorrhiza fungi and Rhizoboum. Plant Soil 108:111-115
Dhole VJ, Reddy KS (2015) Genetic variation for phytic acid content in mungbean (Vigna radiata L. Wilczek). The Crop J. 3(2):157-162

Dubois M, Gilles KA, Hamition JK, Rebers PA, Smith F (1956) Colorimetric method for determination of sugars and related substances. Anal. Chem. 28:350-356

El-Umolari LK, Rengasamy R (2012) Synergistic effect of seaweed manure and Bacillus sp. On growth and biochemical constituents of Vigna radiate L. J. Biofertil. Biopestici 3(3):1-7

Essa RE (2105) Response of some field crops to slow release fertilizers. Ph.D. Thesis, Soil Sciences Depart., Faculty Agric., Cairo University, Egypt.

Essa RE, Khattab EA, Ahmed MA, Manal FM (2019) Production of mungbean under fertilization some slow fertilizers. Biosci Res 16(1):878-887

Fernandes P, Bhalerao SA (2015) Effect of bio-fertilizer on the growth and biochemical parameters of Mungbean Vigna radiata (L, Wilczek). Int J Adv Res Biol Sci 2(4):127-130

Ganesh RJ, Chaudhary DR, Khadse VA, Zodape ST (2015) Utilisation of seaweeds in enhancing productivity and quality of blackgram [Vigna mungo (L.) Hepper] for sustainable agriculture. Indian J Nat Prod Resour 6(1):16-22

Goel AK, Laura RDS, Pathak G, Anuradhaand G, Goel,A, (1999) Use of biofertilizers: potential, constraints and future strategies review. Int J Trop Agric 17:1-18

Gupta PK, Nikhil K, Mayank K (2015) Phytoremediation of waste water through aquatic plants for the change detection analysis in the chemical properties within the district Dhanbad. Jharkhand Intern J Res Eng Technol 4(2):243-252

Kung LJ, Lim JM, Hudson DJ, Smith JM, Joerger RD (2015) Chemical composition and nutritive value of corn silage harvested in the northeastern United States after Tropical Storm Irene. J Dairy Sci 98(3):2055-2062

Latique S, Chernane H, Mansori M, EIKaoua M (2013) Seaweed liquid fertilizer effect on physiological and biochemical parameters of bean plant (Phaseolus vulgaris) under hydroponic system. Euro Scient J 9:174-191

Marrez DA, Naguib MM, Sultan YY, Daw ZY, Higazy AM (2014) Evaluation of chemical composition for Spirulina platensisin different culture media. Res J Pharm Biol Chem Sci 5(4):1161-1171

Nelson DW, Sommers L (1982) Total carbon, organic carbon, and organic matter 1. Methods of soil analysis. Part 2. Chemical and microbiological properties, (methodsofsoilan2), 539-579.

Nikhil K (2014) Development of algae-based technology to mitigate energy crisis in coal mining areas: a critical review. Intern J Environ Technol Manag 17(2-4):334-363

Ruby AS, Mala R (2014) Fabrication of nano structured slow release fertilizer system and its influence on germination and biochemical characteristics of Vigna Raidata. Intern J Chem Technol Res 6(10):4497-4503

Sahar MZ (2017) Effect of P-fertilizer and micronutrient (Fe and Mo) on seeds yield of soybean and its quality under sandy soil condition. Menoufia J Soil Sci 2:211-225

Samman S, Chow JWY, Foster MJ, Ahmad ZI, Phuyal JL, Petocz P (2008) Fatty acid composition of edible oils derived from certified organic and conventional agricultural methods. Food Chem 109:670-674

Snedecor GW, Cochran WG (1990) Statistical methods, 7th edn. The lowa State University, Ames, p 507

Trenkel ME (2010) Slow and controlled release and stabilized fertilized: An option for enhancing nutrient use efficiency in agriculture. Intern. Fert. Industry Assoc. (IFA), Paris, France, p 163.

Venkata Rao P, Reddy AS, Koteswara Rao Y (2015) Effect of seaweed liquid fertilizers on productivity of Vigna radiata (L). Wiliczek Int J Res Chem Environ 5(4):91-94

Vyomendra C, Kumar N (2016) Effect of Algal Biofertilizer on the Vigna radiata: a critical review. J Eng Res Appl 6(2):85-94

Wahane MR, Meshram NA, More SS, Khobragade NH (2020) Bio-fertilizer and their role in sustainable agriculture: a review. Pharm Innov J 9(7):127-130

Zodape ST, Soumita M, Eswaran K, Reddy MP, Chikara J (2010) Enhanced yield and nutritional quality in green gram (Phaseolus radiata L.) treated with seaweed (Kappaphycus alvarezii) extract. J Sci Ind Res 69(6):468-471

\section{Publisher's Note}

Springer Nature remains neutral with regard to jurisdictional claims in published maps and institutional affiliations. 